\title{
On the Nexus of Credit Risk Management and Bank Performance: A Dynamic Panel Testimony from Some Selected Commercial Banks in China
}

\author{
Tan Zhongming1, Rethabile Mpeqa ${ }^{1 *}$, Isaac Adjei Mensah ${ }^{2}$, Guoping Ding1, Mohammed Musah ${ }^{1}$ \\ ${ }^{1}$ School of Finance and Economics, Jiangsu University, Zhenjiang, China \\ ${ }^{2}$ Institute of Applied Systems and Analysis (IASA), Faculty of Science, Jiangsu University, Zhenjiang, China \\ Email: tzmyx@mail.ujs.edu.cn, *rmpeqa@yahoo.com, isaacadjeimensah29@ou tlook.com
}

How to cite this paper: Tan, Z. M., Mpeqa, R., Mensah, I. A., Ding, G. P., \& Musah, M. (2019). On the Nexus of Credit Risk Management and Bank Performance: A Dynamic Panel Testimony from Some Selected Commercial Banks in China. Journal of Financial Risk Management, 8, 125-145. https://doi.org/10.4236/jfrm.2019.82009

Received: May 8, 2019

Accepted: June 21, 2019

Published: June 24, 2019

Copyright $\odot 2019$ by author(s) and Scientific Research Publishing Inc. This work is licensed under the Creative Commons Attribution International License (CC BY 4.0). http://creativecommons.org/licenses/by/4.0/

\begin{abstract}
This study empirically examines the liaison amid credit risk management and bank performance in a multivariate framework using bank size, non-performing loans, real GDP, net income, inflation and return of total assets to loans as indicators of credit risk and return of assets as a proxy of bank performance for some selected commercial banks in China from 2006-2017. With the application of panel econometric approaches that account for the issues of cross-sectional dependence and heterogeneity, results from the P-Y homogeneity test, Pesaran $\mathrm{CD}_{\mathrm{LM}}$ test, CIPS panel unit root test, Pedroni and Durbin-Hausman panel cointegration, the AMG estimator and the DH panel Granger causality test show that: 1) the panel time series data are heterogeneous and cross-sectionally dependent; 2) analyzed variables are integrated are of the same order $(\mathrm{I}(1)) ; 3)$ there exists a structural long-run relationship amongst the analyzed variables; 4 ) non-performing loan has a mitigating impact on bank performance, whereas net income and bank size have positive effect on bank performance. Real GDP and inflation impact negatively on bank performance but insignificant whilst the ratio of total assets to loans on the other hand also has a statically insignificant but positive effect on bank performance; 5) a variety of causal relationships are identified amongst analyzed variables; 6) conclusions as well as policy implications are efficient and robust since this study utilizes econometric techniques addresses the issues of heterogeneity and cross-sectional dependence.
\end{abstract}

\section{Keywords}

Credit Risk, Bank Performance, Heterogeneity, Cross-Sectional 
Dependence, China

\section{Introduction}

Management of credit is tense mainly with using the bank's resource both efficiently and lucratively to achieve preferable economic growth. Altogether, it also seeks a fair distribution among the various segments of the economy so that the economic fabric grows without any hindrance as stipulated in the national objectives, in broad, and the investment objectives in particular. Consistently credit management involves the presence of bad debts and its management. Whatever effort that credit managers put in place, there is always the occurrence of bad debts; assessment of credit management, therefore, must involve methods of debt recovery (Kumbhar, 2009). On the other hand, Madhavi \& Prasad (2015), explain that financial management has a straight influence on the effectiveness of the company when management of working resources is regarded as essential in relations of liquidity and profitability. The bond between the management of credit and financial performance of banks has currently become an issue of focus that has captured a lot of theoretical debates among policymakers, academicians, and banks practitioners. First, the businessperson has the responsibility to pay the commitment due to the bank according to the specified and signed contract terms and second, the bank has an obligation to hold the businessperson in debts and to clear the businessperson of all credits after the debt has been paid (Diamond \& Rajan, 2006). It is a contract requiring the fulfillment of tasks on both parties and default in those requirements by either party may have negative consequences on the connection between the parties, such as refusal to grant future loans to a defaulter (Graeber, 2011). The bank has the duty to disbursement and the debtor has the commitment to pay his/her debt. According to Kiselakova and Kiselak (2014) the management of credit portfolios is one the paramount imperative tasks for the financial institution and permanency of banking sector in linking with the increased compassion of banks credit risks and changes in the growth of values of financial instruments. In management and maximization of credit risk, the willpower of each individual loans, or borrower, risk assessment techniques plays a primary role. To determine the risk represented, it's necessary to accomplish the loan collection as a complete by an individual borrower and by respectively individual credit service.

Recent economic crunch has highlighted that a well established financial system is the basic ingredient for the economic growth. It enables an economy to be flourishing as it facilitates investors with few resources to utilize savings from those with few prospects of investing. In this regard it is crucial to now hat factors drives banking profitability. Higher profitability not only accelerate more financing to the economy it is also good for regulators as it guarantees more flexible capital ratios. Additionally higher profitability must lead to higher returns to shareholders which is the ultimate goal of the management of any bank. 
Despite all the above facts an financial reforms in China taken since 1990's, with an aim of improving profitability, efficiency and productivity, banks performance has still remained poor concluded by (Francis, 2010). A substantial amount of literature available shows that poor performance manifest into lower performance of bank factors including poor quality of loans, higher level of liquidity risk and higher amount o non-performing loan ratios among others. Although above said are the main hurdles affecting Chinese banks Chi \& $\mathrm{Li}$, (2017), demonstrated that higher government ownership ratio is the cause of risk taking in different businesses. Shih et al. (2007) examined the profitability of the big four, joint stock and city commercial banks through principal analysis and concluded that joint stock banks are better than the state owned banks. This lower profitability demonstrates the lack of competiveness in the Chinese banking sector. All these studies among others show understanding on Chinese banking sector. Thus there is strong need to explore what explains the profitability of the Chinese banking. Concerning the aforementioned issues in the banking industry of China in relation to particularly bank performance and profitability, the gap in literature with respect to bank performance in connection both internal and external factors calls for deeper investigation. Additionally, in terms minimizing the earlier posed issues such as credit risk and others in relation to bank performance, identifying the factors affecting banking performance is necessary. This current paper therefore seeks to fill the space by providing detailed analysis on the effect of credit risk indicators on bank performance in the Chinese context.

Though numerous researches have been conducted on the relationship amid bank performance and management risk of banks globally, this paper contributes to literature for the first time by exploring the effect of real gross domestic product, bank size, inflation, bank size, ratio of total assets to loans, non-performing loans and net income as measures of credit risk management and return of asset as a proxy of financial performance for 6 banks in China from 2006-2017 based on AMG approach. Secondly, though there exist quite a number of researches examining the effect of credit risk management on financial performance, those utilizing the panel case often use econometric methods that assume and/or cross-sectional independence and/or homogeneity. Counting on cross-sectional independence and homogeneity alone is likely to yield spurious results in case the panel being used is actually cross-sectionally reliant and heterogamous. Thus unlike other studies, we employ a homogeneity test by Pesaran et al. (2008) as well as cross-sectional reliance test by Pesaran (2004) so as to affirm that the panel times series data used in the study has cross-sectional connectedness and as well heterogeneous. The study therefore compared to aforementioned researches applies panel estimation methods that very efficient and robust to the presence of cross-sectional dependence and heterogeneity.

The rest of the paper is structured as follows: Section 2 gives brief information on the empirical literature where Section 3 focuses on the methodology of the 
study in general. Section 3 empirically discusses the findings whereas Section 4 summarily gives the conclusion together with some policy implications.

\section{Literature Review}

\subsection{Brief History of the Banking Industry in China}

As the country with the fastest economic growth, China has experienced rapid economic growth in the past three decades. During this period, banking reform played an important role in economic development. The Chinese banking industry was monopolized by the People's Bank of China as early as 1979. In 1980, four state-owned banks, Bank of China (BOC), Industrial and Commercial Bank of China (ICBC), Agricultural Bank of China (ABC) and China Construction Bank (CCB), were established. The business of each bank is strictly limited to a specific department. Since 1998, state-owned professional banks have transformed into commercial banks. As the central bank of China, the People's Bank of China manages the money supply through a series of monetary policies. Later, over time, in order to improve efficiency and corporate governance, commercial banks began a shareholding system reform. After divesting non-performing assets and two rounds of capital injection in 1998 and 2003, the government took the lead in transforming commercial banks into joint-stock entities. This move paved the way for the Chinese banking industry to embark on the "marketization" road. Later, threefold improvement in the liberalization of the banking system played an important role in shaping a decent banking system. The first modern corporate governance practice for the global market was welcomed and implemented by the banking business. Second, the government promotes the development of the banking industry by introducing preferential bank spread policies. The most recent since 2007, the Chinese government has opened its doors to foreign companies and allowed them to work in the renminbi. The entry of international banks has promoted the efficiency and competition of domestic banks. By 2010, all state-owned banks have successfully completed an initial public offering (IPO) and transformed into a public company. At the same time, these reforms have greatly improved the financial efficiency of the Chinese banking industry. According to the "Banker" report, as of 2016, four banks including Industrial and Commercial Bank of China, China Construction Bank, Bank of China, and Agricultural Bank of China all entered the top five global capital.

The supervision of foreign subsidiaries and branches has gone through three stages. Before 1994, the financial industry was limited in its openness. The business of foreign subsidiaries is limited to the foreign exchange business of foreign-invested enterprises and the Shanghai and Shenzhen regions. The Regulations of the People's Republic of China on the Administration of Foreign-funded Financial Institutions (1994) allows foreign branches to conduct foreign exchange business within and outside China. In November 2011, China joined the World Trade Organization (WTO) and responded to financial markets in ac- 
cordance with WTO commitments. Regulations governing the management of foreign-funded financial institutions in the People's Republic of China (2011) and the provisions of the Regulations on the management of foreign-funded financial institutions in the People's Republic of China (2004), gave free foreign exchange business, whether in geography or customer type. However, foreign affiliated banks were subject to special permits and restrictions when they started operations. The regulator provides national treatment to foreign affiliates and branches, but is limited to foreign currency operations. After 2006, foreign and local currency businesses are fully open, and there are no restrictions on branches and branches. Foreign banks begin to collect deposits from the public without any restrictions, such as permits or permits. Supporting the invention of modern and innovative financial products, the examination and approval system was changed to the filing system, which promoted product innovation. At the same time, learn from the core principles of Basel. There is no doubt that foreign banks have their own advantages in retail banking, foreign exchange business, and financial innovation and intermediary.

\subsection{Credit Risk and Bank Performance}

Although there has been a lot of research on the relationship between bank performance and credit risk management in the world, there are very few studies on Chinese banks that use the recently developed panel econometric method. Regarding previous researches among others, Edwin \& Omagwa (2018) determined the effect of credit risk management practices (client proposal, credit risk, collection of policy and terms) bank performance of MFI's in Nairobi Central business district. By employing a multi regression analysis, they evidenced that, credit risk control, client proposal; collection policy and terms of credit risk are all statistically significant in explaining bank performance. In the case of panel time series analysis, Kajola et al. (2018) explored the effect of credit risk management on the bank performance of 10 listed banks also in Nigeria for the period of 2005-2016. Using the random effect generalized least square (REGLS) regression as an estimation method, all three parameters of credit risk (Nonperforming loans to total loan ration (NPLLR), Non-performing loans to total deposit ratio (NPLDR) and capital adequacy ratio (CAR)) were identified to have significant liaison with return of assets (ROA) and return on equity (ROE) which as proxies of bank performance. In the context of Sri-Lanka, Rasika \& Sampath (2015) also in the same area of research quantitatively investigated the effect of credit risk on bank performance of commercial banks with reference to systematically important banks from 2011-2015 on a quarterly financial report. Adopting return of equity (ROE) as a proxy of financial performance while Non-performing loan ratios (NPLR) and capital adequacy ratio (CAR) as credit risk indicators in multivariate framework, it was evidenced that, both NPLR and CAR have negative and statistically significant effect on ROE with NPLR having a higher significant effect on ROA compared to CAR. Further Isanzu (2017) also 
in a panel case, empirically examined the impact of credit risk on bank performance of Chinese banks from 2008-2014 using a balanced panel data regression model. The study as compared to others, measured credit risk using non-performing loans, capital adequacy ratio, loan impairment charges and impaired loan reserve whilst ROA was used as a measure of banks performance. Findings revealed that, non-performing loans and capital adequacy have statistically significant effect on bank performance of Chinese commercial banks. From the Kenyan perspective, Muriithi et al. (2016) in a multivariate framework, employed panel data techniques which includes the fixed effect estimation and generalized method of moments (GMM) in order to assess the effect of credit risk on bank performance of commercial banks from 2005-2014. Per their findings, credit risk was identified to have a negative and significant relationship with bank profitability whereas high non-performing loans to total assets as an indicator of credit risk management related significantly to poor bank performance both in the long-term and short-term. The above articles generally analyzed the effect credit risk management on financial performance of banks using different measurement variables as well as different regions together with different methods.

Perhaps the most compelling rationale for authors to pursue the effect of credit risk on bank performance is because credit risk causes variability of profits which in turn leads to a reduction in the banks' earnings. Significant loss of earnings can lead stakeholders losing confidence in the performance of the banks' operations, reduces credit available for perspective loan applicants and as well causes failure to meet its obligations and subsequent loss of the strategic bank position in the industry. At times credit risk can cause the withdrawal of license or charter and even bankruptcy. It is therefore for this reason the current study centers on investigating the impact of credit risk on performance of banks in order to help understand the effect, coagulate the need for allocating time and resources for effective credit risk management.

\section{Methodology}

\subsection{Data Source and Description}

The study uses a panel time series data of 6 banks in China covering the period from 2006 to 2017 for the variables which includes bank size, return of assets, inflation, real gross domestic product, inflation, ratio of total asset to loans and non-performing loans. The data with respect to the aforementioned variables were obtained from audited statements of 6 banks as well as the World Bank development indicator (WDI, 2015). The data per each variable is transformed into natural logarithm so as to interpret a parameter estimates as elasticities of the response variable. The overall period (2006-2017) together with the sampled banks for the study were dictated by data availability. Sampled banks for this study covers, Industrial Commercial Bank of China (ICBC), Bank of China, Bank of Communication, China Construction Bank, Agriculture Bank of China, 
and CITIC Bank. Table 1 therefore presents the summary of data source whilst Table 2 on the other hand gives the information on the descriptive statistics (mean, standard deviation, skewness kurtosis and JB test of normality) of the variables whereas Figure 1 illustrates the profile of the aforementioned variables (all in natural logarithm during the period of 2006-2017) with time. The trending of the graphs could give the implication that the variables used in the study are non-stationary. This as result should further be confirmed by panel unit root test which presented in the subsequent section.

The descriptive statistics as presented in Table 2 depicts that, all banks sampled for the study are profitable with a very marginal average return of asset of $0.791 \%$ with a standard deviation of 0.244 . Averagely, $0.560 \%$ of the loans in various banks are non-performing; this is fairly small with a standard deviation of 0.628 . This gives the indication that averagely a substantial percentage of loans of Banks in China are performing which as result enhances their profitability. Inflation rate on the other hand had double digit average value of $12.629 \%$ which indicates some level of macroeconomic stability has the tendency to affect economic growth negatively. Comparatively real GDP had the highest average value of $29.552 \%$ with a standard deviation of 0.485 indicating that a country like China has a strong and fast growing economy. On the average the ratio of total assets to loans was obtained as $3.894 \%$ with a standard deviation of 0.581 . The remaining variables bank size and inflation respectively had the averages $16.566 \%$ and $0.876 \%$ respectively. With respect to the skewness all variables were negatively skewed, flattering to the left with the exception of NPL and ROA that are positively skewed, flattering to the right. On the side of kurtosis, the values of INF and RGDP were lower than the normal value suggesting the kurtosis curve is platykurtic. On the other hand, BS, NI, NPL, ROA and RTL had their kurtosis values to be respectively above the normal value indicating that the aforementioned variables with respect to shape are leptokurtic. In general, for the

Table 1. Data source summary.

\begin{tabular}{|c|c|c|c|}
\hline Variable & Symbol & Description & Source \\
\hline Bank size & BS & Ownership assets by banks & $\begin{array}{l}\text { Almanac of China's } \\
\text { Finance and Banking }\end{array}$ \\
\hline Non-Performing loans & NPL & $\begin{array}{l}\text { A loan is said to non-performing when more than } 90 \text { days pass } \\
\text { without the borrower paying the agreed installments }\end{array}$ & $\begin{array}{l}\text { Almanac of China's } \\
\text { Finance and Banking }\end{array}$ \\
\hline Return on Assets & ROA & $\begin{array}{l}\text { An indicator of banks profitability and measures deposit takers } \\
\text { efficiency in the use of assets }\end{array}$ & $\begin{array}{l}\text { Almanac of China's } \\
\text { Finance and Banking }\end{array}$ \\
\hline Net income & IN & $\begin{array}{l}\text { The amount of individual earns after subtracting taxes and other deductions } \\
\text { from gross income }\end{array}$ & $\begin{array}{l}\text { Almanac of China's } \\
\text { Finance and Banking }\end{array}$ \\
\hline $\begin{array}{l}\text { Real gross domestic } \\
\text { product }\end{array}$ & RGDP & $\begin{array}{l}\text { This is an inflation adjusted measure that reflects the value of all goods and } \\
\text { services by an economy in a given year, expressed in base-year prices. }\end{array}$ & WDI \\
\hline Inflation & INF & Measured as the consumer price index on annual basis with 2000 as base year & WDI \\
\hline $\begin{array}{l}\text { Ratio of total } \\
\text { assets to loans }\end{array}$ & RTL & $\begin{array}{l}\text { This is an indicator of financial leverage. It tells the percentage of total assets } \\
\text { that are financed by creditors, liabilities and debt. }\end{array}$ & $\begin{array}{l}\text { Almanac of China's } \\
\text { Finance and Banking }\end{array}$ \\
\hline
\end{tabular}


Table 2. Descriptive statistics.

\begin{tabular}{cccccccc}
\hline Variable & BS & NI & NPL & INF & RGDP & ROA & RTL \\
\hline Mean & 16.556 & 12.629 & 0.560 & 0.876 & 29.552 & 0.791 & 3.894 \\
Std. Dev. & 1.783 & 1.535 & 0.628 & 0.595 & 0.485 & 0.244 & 0.581 \\
Skewness & -0.358 & -0.947 & 2.403 & -0.115 & -0.556 & 0.684 & -1.471 \\
Kurtosis & 4.237 & 5.100 & 10.432 & 2.447 & 1.998 & 3.304 & 13.979 \\
JB test & $5.109^{*}$ & $19.999^{* * *}$ & $195.852^{* * *}$ & $10.599^{* * *}$ & $5.599^{*}$ & $2515.295^{* * *}$ & $323.030^{* * *}$ \\
p-value & 0.078 & 0.000 & 0.000 & 0.001 & 0.061 & 0.000 & 0.000 \\
Observations & 60 & 60 & 60 & 60 & 60 & 60 & 60 \\
\hline
\end{tabular}

Note: All variables are transformed into natural logarithm. ${ }^{\star}$ and ${ }^{\star * *}$ indicates the rejection of the null hypothesis of the Jarque-Bera test at $10 \%$ and $1 \%$ level of significance. The JB test is used to determine whether the given series follows a normal distribution or not.
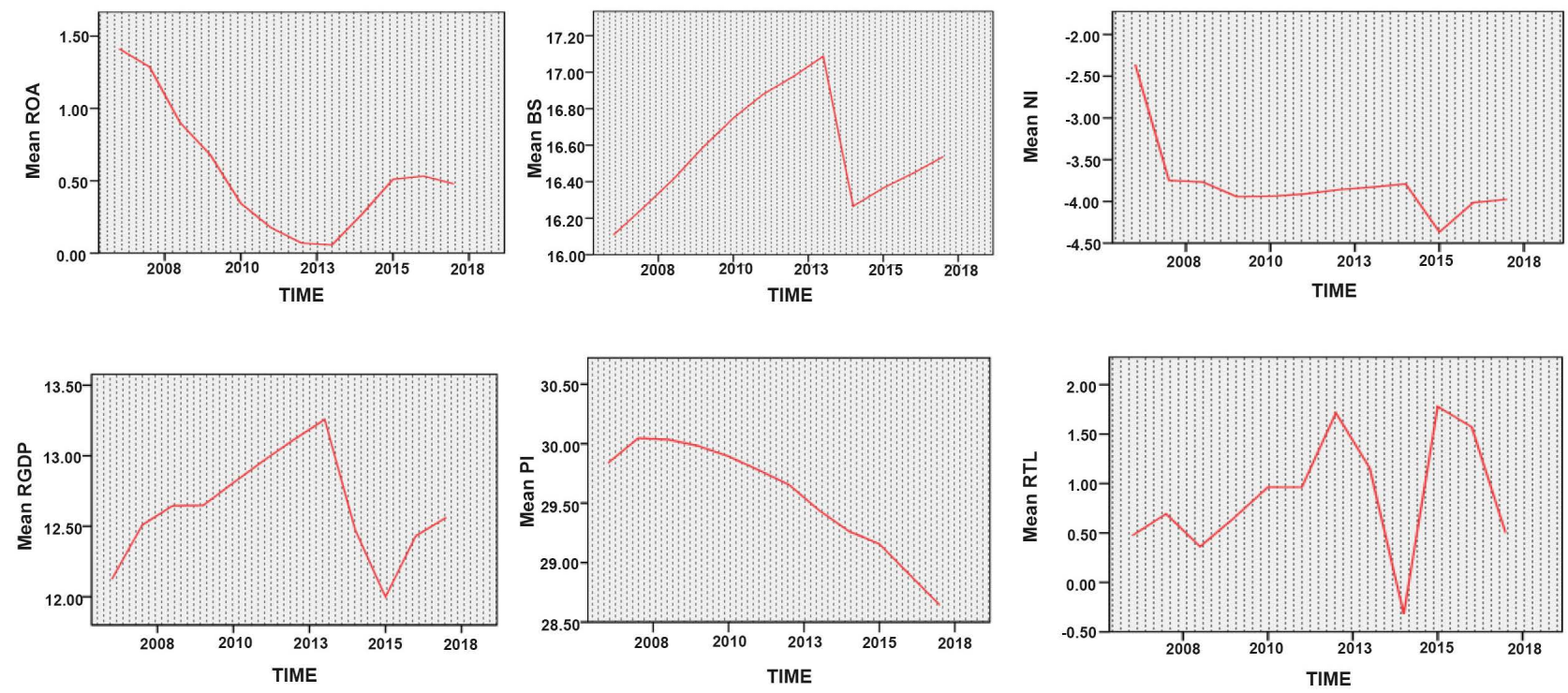

Figure 1. Data trends of variables from 2006-2017.

series to be normally distributed, the skewness must be 0 whilst the kurtosis is 3 . Having confirmed that none of the variables satisfies the conditions of normality; we therefore conclude that the series is not normally distributed. This is in line with Jarque-Bera test which rejects the null hypothesis of series being normally distributed for all variables. Therefore, the series is not normally distributed.

The study went further to test for multicolinearity to determine whether the explanatory variables used in the study are independent of each other. Table 3 illustrates the correlation matrix together with the variance inflation factor (VIF) and tolerance values for the respective independent variables. As presented, the correlation coefficients amid the independent variables are far less than 0.7. Further, the VIF and tolerance are used in checking for multicolinearity. The VIF values for independent variables are less than 0.5 whereas the values for test statistic (Tolerance) are far greater than 0.2. This as a result suggests that, there exist no issues of multicolinearity among variables within the regression model used in the study. 
Table 3. Multicolinearity test.

\begin{tabular}{ccccccccc}
\hline Variables & BS & NPL & NI & RGDP & INF & RTL & VIF & Tolerance \\
\hline BS & 1 & -0.249 & 0.339 & 0.015 & 0.076 & -0.288 & 0.280 & 0.503 \\
NPL & & 1 & -0.253 & 0.245 & -0.221 & 0.134 & 1.242 & 0.805 \\
NI & & & 1 & 0.051 & 0.032 & -0.215 & 0.345 & 0.407 \\
RGDP & & & & 1 & -0.169 & -0.268 & 1.227 & 0.815 \\
INF & & & & & 1 & 0.130 & 1.119 & 0.893 \\
RTL & & & & & & 1 & 1.314 & 0.761 \\
\hline
\end{tabular}

Note: All variables are transformed in to natural logarithm. This table assesses the correlations between the independent variables in order to check for multicolinearity. Values in the table are obtained from the pairwise correlation which is computed using the relation $\sum_{i=1}^{n}\left(x_{1 i}-\bar{x}_{1}\right)\left(x_{2 i}-\bar{x}_{2}\right) / \sqrt{\sum_{i=1}^{n}\left(x_{1 i}-\bar{x}_{1}\right)^{2}} \sqrt{\sum_{i=1}^{n}\left(x_{2 i}-\bar{x}_{2}\right)^{2}}$.

\subsection{Model Specification}

This current study estimates the relationship amid credit risk management and performance of some selected banks in China using bank size, inflation, real gross domestic product, ratio of total asset to loans and non-performing loans as measurement variables for management of credit risk in a multivariate framework. Our study in terms of variables selection is quite similar to that of Ebrahim et al. (2016) who investigated the determinants of credit risk and its implication on bank performance in Yemen using ratio of total loans to total assets, non-performing loans, gross domestic product and inflation as indicators of credit risk. Comparatively, this current study included net income and bank size in addition to the aforementioned variables as indicators of credit risk. Hence our proposed model concerning the effect of credit risk management on bank performance takes the following form;

$$
B P_{i t}=f\left(C r d M_{i t}\right)
$$

where $B P_{i t}$ represents bank performance measured using return on assets $(\mathrm{ROA})^{1}, C r d M_{i t}$ is credit risk management $i$ stands for the individual banks whilst $t$ represents time in years.

Since credit risk is measured using the measurement variables; bank size, return on assets, inflation, real gross domestic product (GDP), ratio of total loans to total assets, net income and non-performing loans Equation (1) can be reformulated as;

$$
R O A_{i t}=f\left(B S_{i t}, I N F_{i t}, r G D P_{i t}, R T L_{i t}, N P L_{i t}, N I_{i t}\right)
$$

where $R O A$ represents return on assets used a proxy of bank performance (BP), BS is bank size, INF denotes inflation, $r G D P$ is real gross domestic product, RTLA also mean ratio of total loans to total assets, NPL on the other hand stands for non-performing loans and NI represents net income.

${ }^{1}$ Subsequent equations ROA (return of assets) will be used in place of BP (bank performance) since bank performance is measured using the former variable (ROA). 
For the purpose of econometric estimation and also since the study solely focuses on a panel data involving six (6) commercial banks in China from 2006 to 2017, Equation (2) can further be written in a panel model form as follows;

$$
R O A_{t}=\beta_{o}+\beta_{1} r G D P_{i t}+\beta_{2} B S_{i t}+\beta_{3} I N F_{i t}+\beta_{3} R T L_{i t}+\beta_{3} N P L_{i t}+\beta_{3} I N_{i t}+\mu_{i t}
$$

In order to address issues of heteroskedasticity, all the variables included in the proposed financial performance function in Equation (2) are transformed into natural $\operatorname{logarithm}$. The log-linear model used to analyze the effect of credit risk on bank performance is thus formulated as:

$$
\begin{aligned}
\ln R O A_{i t}= & \beta_{o}+\beta_{1} \ln r G D P_{i t}+\beta_{2} \ln B S_{i t}+\beta_{3} \ln I N F_{i t} \\
& +\beta_{3} \ln R T L_{i t}+\beta_{3} \ln N P L_{i t}+\beta_{3} \ln I N_{i t}+\mu_{i t}
\end{aligned}
$$

where $\ln r G D P_{i t}, \ln B S_{i t}, \ln P I_{i t}, \ln R T L_{i t}, \ln N P L_{i t}$, and $\ln I N_{i t}$ are the natural logarithms of real GDP, bank size, inflation, ratio of total asset to loans, non-performing loans and interest rate of an individual bank $i$ at time $t$ respectively and $\mu_{i t}$ represents the individual error terms.

\subsection{Econometric Approach}

Cross-sectional correlations and homogeneity among variables in a panel time series data shows the significance for the selection of further econometric techniques used in the analysis such as unit root tests and cointegration tests. Hence, the study first tested whether cross-sectional correlations exist among the series with the panel data of banks in China with the Pesaran $\mathrm{CD}_{\mathrm{LM}}$ test developed by Pesaran (2004) and as well tested for the existence of homogeneity with adjusted delta tilde by Pesaran \& Yamagata (2008). The study later analyzed the integration properties (stationarity test) with the Cross-sectional IPS (CIPS) panel unit root test of Pesaran (2007) that accounts for the issues of cross-sectional correlations and heterogeneity. After examining the integration properties of the series, it was of interest to pin down to investigate the structural long-run relationship among the variables used in the study using the Pedroni (1999) and Westerlund (2008) panel cointegration test. This panel cointegration test compared to the CIPS unit root also works well in the presence of heterogeneity and cross-sectional correlations. The study then estimated the structural long-run cointegration relationship with the Augmented Mean Group (AMG) estimator developed by Eberhardt \& Teal (2011). Finally in order to determine the nature of causal relationships amid the variables, the study employed a recently developed panel causality test by Dumitrescu \& Hurlin (2012) which also accounts for the issue of cross-sectional dependence.

\section{Empirical Findings}

\subsection{Homogeneity and Cross-Sectional Correlation Tests}

With the intention of determining whether the slope coefficients are homogenous or heterogeneous, this paper uses the Pesaran et al. (2008) homogeneity test 
that builds on the Swamy approach to estimate delta and the adjusted delta in order to test the null hypothesis of slope homogeneity

( $H_{o}: \alpha_{i}=\alpha$, for all series), versus the alternative hypothesis of slope heterogeneity $H_{o}: \alpha_{i} \neq \alpha_{j}$, for non-zero pairwise slopes fraction i.e. $i \neq j$. In addition to the homogeneity test, we employed as earlier mentioned the Pesaran- $\mathrm{CD}_{\mathrm{LM}}$ test to the various cross-sections within the panel time series data to examine whether or not the individual series are cross-sectionally independent. The study employed the $\mathrm{CD}_{\mathrm{LM}}$ test in the data set and suggests the following test statistic exhibiting asymptotically normal distribution with a null hypothesis of crosssectional independency:

$$
C D_{L M}=\sqrt{\frac{1}{N(N-1)}}\left(\sum_{i=1}^{N-1} \sum_{j=i+1}^{N}\left(2 \rho_{i j}^{2}-1\right)\right)
$$

The result based on the Pesaran $C D_{L M}$ test as well as the Pesaran-Yamagata homogeneity tests are introduced in Table 4 . Considering the p-value of the $C D_{L M}$ test we reject the null hypothesis of cross-sectional independence at $1 \%$ level of significance, because the p-value of this statistic is found to be 0.0001 $(<0.01)$. This therefore gives the indication that, there exist cross-sectional dependencies among series in the panel data. Furthermore, with respect to the homogeneity test using the Delta_tilde and Delta_tilde adj, the findings reveal that the null hypothesis of homogeneity is rejected also at $1 \%$ significant level indicating that, the slope coefficients are heterogeneous across all cross-sections. We therefore conclude that, the panel time series data used for the study has cross-sectional dependence among the series and also heterogeneous. Thus the study as mentioned already employs panel data methods that are robust to cross-sectional correlations and heterogeneity.

\subsection{Panel Unit Root}

In order to assess the stationarity properties of the variables employed, this paper as already mentioned used the CIPS panel unit root test due to the presence of cross-sectional correlations and heterogeneity. Since the CIPS unit root test gives accurate results in the presence of both heterogeneity and cross-sectional correlation, we prefer this second generation unit root test compared to the first

Table 4. Results from the homogeneity test and cross-sectional correlation.

\begin{tabular}{ccc}
\hline & Cross-sectional correlation test & \\
\hline Test & Statistic & p-value \\
\hline $\mathrm{LM}_{\mathrm{CD}}($ Pesaran, 2004) & $2.487^{* * *}$ & 0.0001 \\
\hline & Homogeneity test & 0.000 \\
\hline Delta_tilde & $2.296^{* * *}$ & 0.000 \\
\hline
\end{tabular}

Note: ${ }^{* *}$ and ${ }^{* *}$ represents the rejection of the null hypothesis at $1 \%$ and $5 \%$ level of significance respectively. 
generation tests such as LLC, IPS and ADF unit root test. The CIPS unit root test exhibits an asymptotically normal distribution and is calculated as follows:

$$
C I P S=N^{-1} \sum_{i=4}^{N} C A D F_{i}
$$

whereas the CADF (Cross-sectional Augmented Dicky-Fuller) unit root is estimated using the ordinary least square (OLS) approach for each ith cross-section in the panel as:

$$
\Delta y_{i t}=\alpha_{i}+b_{i} y_{i, t-1}+\sum_{j=1}^{\rho_{i}} c_{i j} y_{i, 1-j}+d_{i} t+h_{t} \bar{y}_{t-1}+\sum_{j=1}^{\rho_{i}} \eta \Delta \bar{y}_{t-1}+\varepsilon_{i j}
$$

where $\alpha_{i}$ is a constant, $t$ is trend, $\Delta \bar{y}_{t-1}$ is the delay difference and $\bar{y}_{t-1}$ is the value one term delay of $\bar{y}_{t}$.

Results from the second generation test (CIPS), are outlined in Table 5. The test indicates that of return of assets, real GDP, bank size, inflation, ratio of total asset to loans, non-performing loans and interest rate are not stationary at their respective levels but stationary at their first differences. Hence, the analyzed variables are integrated at the same order or in other words $\mathrm{I}(1)$. The panel times series data should be non-stationary at their levels so as to assess statistically and economically meaningful long-run estimates of the explanatory variables. Since all the analyzed variables are evidenced to be $\mathrm{I}(1)$, this study in the following section applies second-generation panel cointegration tests to identify whether or not the analyzed have a structural long-run relationship. Given that the aforementioned panel cointegration test requires the panel time series be non-stationary at levels, the variables under discussion meet the necessary requirement.

\subsection{Panel Cointegration Tests}

To determine whether the regressions are spurious, the results of the panel cointegration tests must be examined. Given the results, it is appropriate to test the

Table 5. CIPS panel unit root test results.

\begin{tabular}{ccc}
\hline Variables & Level & First difference \\
\hline $\ln R O A$ & $0.494(0.689)$ & $-10.819^{* * *}(0.000)$ \\
$\ln r G D P$ & $-0.167(0.433)$ & $-15.309^{* * *}(0.000)$ \\
$\ln B S$ & $2.363(0.990)$ & $-17.484^{* * *}(0.000)$ \\
$\operatorname{n} I N F$ & $2.648(0.996)$ & $-11.767^{* * *}(0.000)$ \\
$l \ln R T L$ & $1.152(0.875)$ & $-12.408^{\star * *}(0.000)$ \\
$\ln N P L$ & $0.640(0.739)$ & $-13.064^{* * *}(0.000)$ \\
$\ln I N$ & $8.527(1.000)$ & $-21.524^{* * *}(0.000)$ \\
\hline
\end{tabular}

Note: ${ }^{* * *}$ represents the rejection of the null hypothesis at $1 \%$ level of significance. Probability values are presented in parenthesis. 
cointegration relationships between the variables used in the study. This study as mentioned already in the econometric approaches used two kinds of panel cointegration tests which includes the Westerlund-Durbin-Hausman and Pedroni panel cointegration tests. A panel cointegration of return on assets (ROA) (bank performance), which allows for considerable heterogeneity, is implemented as follows:

$$
\begin{aligned}
\ln R O A_{i t}= & \alpha+\beta \ln r G D P_{i t}+\gamma \ln B S_{i t}+\delta \ln I N F_{i t}+\rho \ln R T L_{i t} \\
& +\theta \ln N P L_{i t}+\psi \ln I N_{i t}+\varepsilon_{i t}
\end{aligned}
$$

The Pedroni heterogeneous panel cointegration together with Westerlund-Durbin-Hausman panel cointegration tests are used to test the null hypothesis of non-existence of cointegration against the alternative of cointegration. Specifically the Pedroni panel cointegration test consist of seven different statistics (panel v-statistic, panel rho-statistic, panel PP statistic, Panel ADF statistic, rho-group statistics, PP-group statistics and ADF-group statistics) and uses the following regression in Equation (9)

$$
y_{i t}=\propto_{i}+\delta_{i} T+\sum_{j=1}^{k} \beta_{i j} x_{j i, t}+\varepsilon_{i t}
$$

where $\propto_{i}$ and $\beta_{i j}$ are respectively intercept and slope coefficients that may vary across regions.

As shown in Table 6, the results of the Pedroni cointegration test indicate that the null hypothesis of no cointegration can be rejected by majority of the statistics at $1 \%$ significance level.

Although Pedroni panel cointegration test is commonly used in literature, it has some weakness of relying on the assumption of cross-sectional dependence. Further, failure to take into account the issue of cross-sectional dependence causes loss of efficiency in identifying the cointegration relationship among variables in the panel times series data (Mensah et al., 2019). Therefore the study additionally employs Westerlund-Durbin-Hausman panel cointegration test considered as a second-generation panel cointegration test. This test takes into consideration both the issues of cross-sectional dependence and heterogeneity in identifying the cointegration among variables and thus more efficient compared to the aforementioned first generation panel cointegration test. Results from the Westerlund-Durbin-Hausman panel cointegration test are reported in Table 7. Referring to the p-values of both statistics which includes Durbin-Hausman group statistic and Durbin-Hausman panel statistic, we have evidence to reject the null hypothesis of no cointegration among return on assets, real gross domestic product, ratio of total assets to loans, non-performing loans and net income at $1 \%$ level of significance. We can therefore confidently conclude that the analyzed variables have a structural long-run relationship. More importantly, the finding of cointegration relationship among the aforementioned variables is efficient and accurate since the Westerlund-Durbin-Hausman panel cointegration test handles the problems of heterogeneity and cross-sectional correlations. 
Table 6. Results from the Pedroni panel cointegration test.

\begin{tabular}{ccccc}
\hline \multicolumn{5}{c}{ Common AR coefficients (within dimension) } \\
\hline & Statistic & Prob. Value & Weighted statistic & Prob. Value \\
\hline Panel v-statistic & 3.013 & $0.001^{* * *}$ & 1.080 & 0.139 \\
Panel rho-statistic & -0.750 & 0.227 & -0.834 & 0.202 \\
Panel PP statistic & -7.725 & $0.000^{* * *}$ & -6.964 & $0.000^{* * *}$ \\
Panel ADF-statistic & -8.294 & $0.000^{* * *}$ & -7.708 & $0.000^{* *}$ \\
\hline & Individual AR coefficients (between dimension) & \\
\hline Group rho-statistic & 1.174 & 0.878 & & \\
Group PP statistic & -7.445 & $0.000^{* * *}$ & \\
Group ADF-statistic & -8.610 & $0.000^{* * *}$ & \\
\hline
\end{tabular}

Note: Pedroni panel cointegration test examines the null hypothesis of no cointegration. Under the null hypothesis, all the variables are distributed Normal $(0,1) .{ }^{* *}$ indicates statistical significance of $1 \%$ level.

Table 7. Results from Westerlund-Durbin-Hausman panel cointegration test.

\begin{tabular}{lcl}
\hline & Statistic & p-value \\
\hline Durbin-Hausman group statistic & 2.078 & $0.000^{* * *}$ \\
Durbin-Hausman panel statistic, & 1.493 & $0.004^{\star * *}$ \\
\hline
\end{tabular}

Note: Westerlund-Durbin-Hausman panel cointegration test examines the null hypothesis of no cointegration. Under the null hypothesis, all the variables are distributed Normal $(0,1){ }^{* * *}$ indicates statistical significance of $1 \%$ level.

\subsection{Long-Run Estimates}

An important inference of an empirical study is to estimate the structural long-run parameters on the independent variables once one confirms that the level of bank size, net income, real gross domestic product, inflation and ratio of total asset to loans have a long-term relationship. Many studies with respect to literature use either the ordinary least square estimates (OLS) or the dynamic ordinary least square (DOLS) and/or fully modified OLS (FMOLS); however, these estimation methods may fail to produce efficient as well as accurate long term parameter estimates since the aforementioned estimators are not efficient to heterogeneity and cross-sectional dependencies. Given the presence of heterogeneity and cross-sectional dependence in the panel data, the study employed as mentioned already a second generation estimator that takes into account the aforementioned issues rather than OLS, DOLS and FMOLS. Thus the study employs a second-generation long-run estimator known as the Augmented Mean Group (AMG) estimator. The AMG approach follows a two-stage procedure as;

$$
\begin{gathered}
\Delta R O A_{i t}=\beta_{i}^{\prime} \Delta X_{i t}+\sum_{s=2}^{T} c_{s} \Delta D_{s}+\Delta e_{i t} \\
R O A_{i t}=\alpha_{i}+\beta_{i}^{\prime} X_{i t}+\kappa_{i} \hat{\mu}_{t}+e_{i t}
\end{gathered}
$$

From Equation (9), standard first difference OLS regression with $T-1$ year dummies $D_{s}$ is estimated. The coefficients on the year dummy $c_{s}$ are rec- 
orded and relabeled as $\hat{\mu}_{t}$. In Equation (10), the variable $\hat{\mu}_{t}$ is included to represent the unobservable common factors evolution over time.

Results from the AMG estimator are posted in Table 8. Because the panel data are transformed into their natural logarithms, the coefficients of

$r G D P, B S, I N F, R T L, N P L$ and $I N$ are equal to the elasticities of return of assets which used as proxy of the dependent variable (bank performance) with respect to bank size, net income, real gross domestic product, inflation and ratio of total asset to loans. The AMG long-run estimation results as outlined in Table 8 shows that non-performing loans (NPL) has a mitigating impact on ROA (return of assets) measuring bank performance and also statistically significant at $1 \%$ level. This therefore gives the implication that, all things being equal $1 \%$ increase in NPL will trigger the performance of selected banks for the study to reduce or decline by $0.117 \%$ in the long-run. Contrarily, net incomes (NI) together with bank size (BS) are also identified to have a positive impact on ROA all at $1 \%$ level of significance. This therefore depicts that, all things being equal a percentage increase in both net income and bank size will increase the performance of selected Chinese banks by $0.367 \%$ and $0.134 \%$ respectively. Further, real GDP and inflation (INF) are identified to impact negatively on ROA but insignificant whilst ratio of total assets to loans (RTL) on the other hand also has a statistically insignificant but positive effect on ROA. These results are in consonant with the findings of Ebrahim et al. (2016) for the negative significant effect of NPL on ROA and the negative insignificant impact of rGDP on ROA in Yemen for the period 1998-2013, Kajola et al. (2018) for 10 banks in Nigeria from 2005-2016, Rashika \& Sampath (2015) for Sri-Lanka from 2011-2015 and Isanzu (2017) for Chinese banks from 2008-2014. In the case of bank size, a positive and a statistically significant effect on ROA is evidenced at $1 \%$ level of significance. Conversely, this implies that ceteris paribus, $1 \%$ increase in the size of sampled commercial banks in China is likely to increase performance (ROA) at $0.134 \%$ in the long-run. Summarily, the estimated panel AMG model for the panel of commercial banks shows a good sign of robustness with the reason being that, results give a very substantial Wald Chi-square test value with a statistically significant probability value at $1 \%$ level. This as a result gives the implication that

Table 8. Results from AMG long-run cointegration coefficient estimation.

\begin{tabular}{ccccc}
\hline Variable & Coefficient & Standard error & Z-test value & p-value \\
\hline Lnnpl & $-0.117^{* *}$ & 0.236 & 0.440 & 0.018 \\
Lnni & $0.367^{* * *}$ & 0.112 & 0.695 & 0.000 \\
Lnrgpp & -0.109 & 0.154 & -1.560 & 0.317 \\
Lninf & -0.291 & 0.227 & -1.177 & 0.449 \\
Lnrtl & 0.198 & 0.206 & 0.102 & 0.920 \\
Inbs & $0.134^{* * *}$ & 0.081 & -1.505 & 0.000 \\
\hline
\end{tabular}

Wald Chi-square test value $=397 \mathrm{e}+13^{* * *}$; Probability value $=0.000$. Note: Dependent variable is return of asset used as proxy of bank performance, ${ }^{* *}$ and ${ }^{* * *}$ represents the significance level at $1 \%$. 
the panel AMG model is robust and very accurate to predict the performance of banks in China, thus there exist a significant relationship between ROA and the indicators used in the study.

\subsection{Panel Causality Test}

As documentation in many studies, the confirmation of long-run relationship further implies the existence of causalities among variables. The study therefore documents the Dumitrescu \& Hurlin (2012) granger causality instead of the conventional granger causality test (Pairwise and PVECM granger causality test) due the issues of cross-sectional correlations and heterogeneity. Comparatively, the D-H granger causality test possesses three main merits over the other conventional panel granger causality test: 1) accounts for the issues cross-section dependency; 2) time dimension ( $\mathrm{T})$ and size of the panel $(\mathrm{N})$ are irrelevant; 3) efficient results are obtained in heterogeneous and balanced panels. D-H panel granger causality test suggests the following regression model to test causalities;

$$
Y_{i t}=\beta_{i}+\sum_{m=1}^{M} \delta_{i}^{(m)} Y_{i, t-k}+\sum_{m=1}^{M} \gamma_{i}^{(m)} X_{i, t-k}+\varepsilon_{i, t}
$$

where $\gamma_{i}=\left(\gamma_{i}^{(1)}, \gamma_{i}^{(2)}, \gamma_{i}^{(3)}, \cdots, \gamma_{i}^{(m)}\right), \quad \beta_{i}$ represents the individual fixed effects, $\delta_{i}^{(m)}$ are the parameters being lagged, $M$ also is the maximum lag length and $\gamma_{i}^{(m)}$ represents the slope coefficients. From Equation (10) $\delta_{i}^{(m)}$ and $\gamma_{i}^{(m)}$ together indicates denotes the difference in cross-sectional units.

This granger causality test uses the homogenous non-stationary (HNC) hypothesis which states that;

$$
\begin{gathered}
H_{o}: \gamma_{i}=0, \forall i=1, \cdots, N \\
H_{A}: \gamma_{i} \neq 0, \forall i=1, \cdots, N_{1} \\
\beta_{i} \neq 0, \forall i=N_{1}+1, N_{1}+2, \cdots, N
\end{gathered}
$$

The null hypothesis of the $\mathrm{D}-\mathrm{H}$ granger causality test indicates that there is no causal liaison within the panel (homogenous results) whilst the alternative hypothesis shows there exist a causal relationship in at least one of the cross-sections within the panel (heterogeneous results). The null hypothesis can only be rejected on the basis that the computed probability value is less the level of significance and vice versa.

The long-run estimated coefficients obtained from the AMG estimator undoubtedly give significant inference but does not reveal the Granger causality directions among the analyzed variables. Notwithstanding, it is of interest for authors to find out information concerning the causal liaisons amongst return of assets, real GDP, bank size, inflation, ratio of total asset to loans, non-performing loans and interest rate. Results from the Granger causality test due to Dumitrescu \& Hurlin (2012) are outlined in Table 9. Evidence from the panel causality analysis gives indication that, there exist bidirectional causality between Ratio of total assets to loans (RTL) and return of total assets (ROA) at $1 \%$ level of significance. This as a result validates a feedback hypothesis between the aforementioned variables in the sense that, any increase in RTL will trigger an increase in 
Table 9. Results from Dumitrescu-Hurlin Panel Granger causality test.

\begin{tabular}{|c|c|c|c|c|}
\hline Null hypothesis & $W_{N, T}^{H n c}$ & $\bar{Z}_{N, T}^{H n c}$ & Prob. value & Decision \\
\hline LNRGDP $\rightarrow$ LNROA & $27.34753^{\star * *}$ & $5.20426^{* * *}$ & 0.0000 & \multirow{2}{*}{$\begin{array}{l}\text { Unidirectional causality from } \\
\text { RGDP to ROA }\end{array}$} \\
\hline LNROA $\rightarrow$ LNRGDP & 1.09986 & -0.67004 & 0.5028 & \\
\hline LN INF $\rightarrow$ LNROA & $33.23001^{* * *}$ & $12.03100^{* * *}$ & 0.0000 & \multirow{2}{*}{$\begin{array}{l}\text { Unidirectional causality from } \\
\text { INF to ROA }\end{array}$} \\
\hline $\mathrm{LNROA}_{-} \rightarrow$ LN INF & 1.71597 & -0.48521 & 0.6275 & \\
\hline LNNPL $\rightarrow$ LNROA & $8.11675^{\star}$ & $1.53503^{*}$ & 0.0826 & \multirow{2}{*}{$\begin{array}{l}\text { Unidirectional causality from } \\
\text { NPL to ROA }\end{array}$} \\
\hline LNROA $\rightarrow$ LNNPL & 5.90173 & 0.67052 & 0.6948 & \\
\hline LNNI $\rightarrow$ LNROA & 5.94369 & 0.78311 & 0.4336 & \multirow{2}{*}{ No causality } \\
\hline LNROA $\rightarrow$ LNNI & 4.25826 & 0.27748 & 0.7814 & \\
\hline LNBS $\rightarrow$ LNROA & $15.84145^{\star}$ & $3.75244^{*}$ & 0.0518 & \multirow{2}{*}{$\begin{array}{l}\text { Unidirectional causality from } \\
\text { BS to ROA }\end{array}$} \\
\hline LNROA $\rightarrow$ LNBS & 5.77474 & 0.73242 & 0.4639 & \\
\hline LNRTL $\rightarrow$ LNROA & $77.6768^{* * *}$ & $22.3030^{* * *}$ & 0.0000 & \multirow{2}{*}{$\begin{array}{c}\text { Bidirectional causality between } \\
\text { RTL and ROA }\end{array}$} \\
\hline LNROA $\rightarrow$ LNRTL & $20.9000^{\star * \star}$ & $5.27000^{\star * *}$ & 0.0000 & \\
\hline LNINF $\rightarrow$ LNRGDP & $44.7872^{\star * *}$ & $12.4362^{* * *}$ & 0.0000 & \multirow{2}{*}{$\begin{array}{l}\text { Unidirectional causality from } \\
\text { INF to RGDP }\end{array}$} \\
\hline LNRGDP $\rightarrow$ LN INF & 1.67605 & -0.49719 & 0.6191 & \\
\hline LNNPL $\rightarrow$ LNRGDP & 2.21130 & -0.33661 & 0.7364 & \multirow{2}{*}{ No causality } \\
\hline LNRGDP $\rightarrow$ LNNPL & 5.04306 & 0.51292 & 0.6080 & \\
\hline LNNI $\rightarrow$ LNRGDP & 5.39770 & 0.61931 & 0.5357 & \multirow{2}{*}{ No causality } \\
\hline LNRGDP $\rightarrow$ LNNI & 5.25524 & 0.57657 & 0.5642 & \\
\hline LNBS $\rightarrow$ LNRGDP & 6.41069 & 0.92321 & 0.3559 & \multirow{2}{*}{ No causality } \\
\hline LNRGDP $\rightarrow$ LNBS & 3.09129 & -0.07261 & 0.9421 & \\
\hline LNRTL $\rightarrow$ LNRGDP & 1.40673 & -0.57798 & 0.5633 & \multirow{2}{*}{ No causality } \\
\hline LNRGDP $\rightarrow$ LNRTL & 2.89063 & -0.13281 & 0.8943 & \\
\hline
\end{tabular}

Note: ${ }^{* *}$ represents the rejection of the null hypothesis of no causal relationship between variables at $1 \%$ level of significance. $W_{N, T}^{H n c}$ and $\bar{Z}_{N, T}^{H n c}$ represent the average Wald statistics and standardized statistic for homogeneous non-stationary (HNC) hypothesis.

ROA and vice versa. Also at $5 \%$ level of significance, there exist a unidirectional relationship between real GDP and return of assets (ROA) with the causation running from real GDP to ROA. This implies that real GDP in the long term has positive effect on the profitability or performance of banks select banks in China. Similarly, causation runs from non-performing loans to return of assets (ROA) at $10 \%$ level of significance and does not in the reverse sense. Inflation (INF) and non-performing loans (NPL) as well as inflation (INF) and real GDP with no doubt exhibits a unidirectional relationship running from inflation to non-performing loans and real GDP but not the opposite direction at $1 \%$ significance level. Compared to other causal relationships, another unilateral causal liaison is found extending from bank size (BS) to return of assets (ROA) and not the vice versa at $10 \%$ significance level. This may also imply that bank size is has a direct positive effect on the performance on selected Chinese commercial banks. Inte- 
restingly, we have enough evidence to conclude that there exist no causal relationships amid non-performing loans (NPL) and return of assets (ROA), as well as real GDP to non-performing loans (NPL), net income (NI), bank size (BS), and Ratio of total assets to loans (RTL) and vice versa. Comparatively the findings per the causalities is in consonant with that of Almekhlafi et al. (2016) who also identified a bidirectional causal relationship between Ratio of total assets to loans (RTL) and return of total assets (ROA), unidirectional causality from real GDP to ROA, as well as inflation (INF) to non-performing loans (NPL), Ratio of total assets to loans (RTL) and real GDP all in Yemen from 1990 to 2013.

Results from Table 9 based on the D-H Granger causality test is graphically summarized in Figure 2.

\section{Conclusion}

This current study centered on the nexus of credit risk management and bank performance in some selected commercial banks in China from 2006 to 2017 where bank size, non-performing loans, real GDP, net income, inflation and return of total assets to loans were used to measure credit risk as explanatory variables whereas return of total assets was used as a proxy of bank performance (response variable) in a multivariate framework. The study adopted second generation panel data methods that take into account the issues of cross-sectional correlations and heterogeneity across all the banks for the analyzed variables. Consequently, the results obtained in the current study are accurate, robust and reliable. In summary, the findings and recommendations are outlined as follows:

- By looking at the Pesaran-Yamagata homogeneity test for all variables within the panel data and also applying the Pesaran's $C D_{L M}$ test to the panel time series data, we identify the existence of heterogeneity and cross-sectional dependence across all banks for the analyzed data.

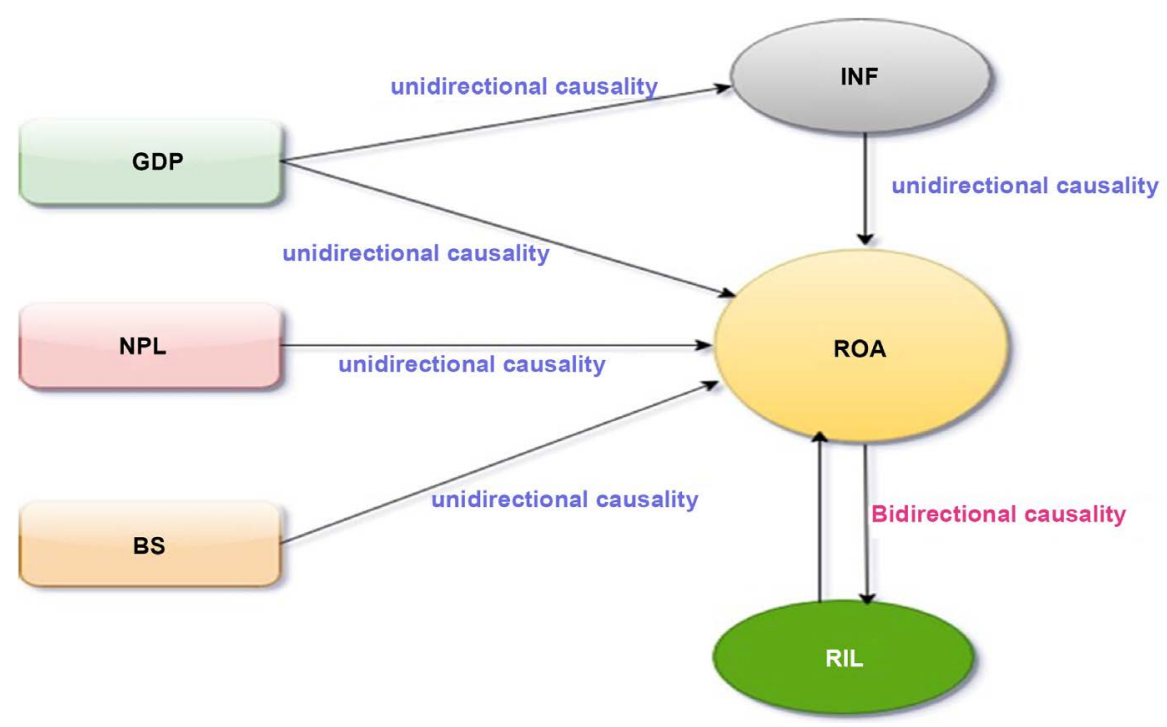

Figure 2. D-H Granger causality network graph for variables used in the study. 
- The CIPS panel unit root test indicates that the analyzed variables are nonstationary at levels but become stationary at their first differences.

- The Pedroni together with Durbin-Hausman panel cointegration tests reveal that the analyzed variables are co-integrated and thus have a structural long-run relationship.

- The AMG estimator in the presence of cross-sectional dependence and heterogeneity indicates that non-performing loans (NPL) has a mitigating impact on ROA (return of assets) measuring bank performance and also statistically significant at $1 \%$ level, net income (NI) and bank size (BS) also at $1 \%$ have positive effect on bank performance, whereas real GDP and inflation (INF) impact negatively on ROA but insignificant whilst ratio of total assets to loans (RTL) on the other hand also has a statically insignificant but positive effect on ROA.

- The panel Granger causality test by Dumitrescu \& Hurlin (2012) shows the existence of bidirectional causality between ratio of total assets to loans (RTL) and ROA (return of assets), and the presence of unidirectional causality extending from real GDP, inflation (INF), bank size (BS) and non-performing loans (NPL) to ROA, as well as inflation (INF) to real GDP.

- The findings from the DH Granger causality test generally support the hypothesis that there exist significant causal relationships between the indicators of credit risk management and performance of banks in China.

Outcomes from this current study have important implications for policy makers, researchers and development partners assisting with the growth process of the banking and financial sector of China. This is due to the fact that, the roles of the banking sector is to mobilize savings, allocate resources and diversify risk. Given that banking systems represents an important share of financial systems in China, a more efficient banking system could positively impact financial development and economic growth if banks can effectively play their financial intermediary role. This can be done if there is much sound credit risk environment and management, judicial and legal support among other considerations. Thus we recommend that, the government should strive to attain sound macroeconomic policy consistent with growth of the banking sector and prudential regulatory requirements to make banks more robust and responsive to the needs of the Chinese populace.

\section{Conflicts of Interest}

The authors declare no conflicts of interest regarding the publication of this paper.

\section{References}

Almekhlafi, E., Almekhlafi, K., Kargbo, M., \& Hu, X. (2016). A Study of Credit Risk and Commercial Banks' Performance in Yemen: Panel Evidence. Journal of Management Policies and Practices, 4, 57-69. https://doi.org/10.15640/jmpp.v4n1a4 
Chi, Q., \& Li, W. (2017). Economic Policy Uncertainty, Credit Risks and Banks' Lending Decisions: Evidence from Chinese Commercial Banks. China Journal of Accounting Research, 10, 33-50. https://doi.org/10.1016/j.cjar.2016.12.001

Diamond, D. W., \& Rajan, R. G. (2006). Money in a Theory of Banking. American Economic Review, 96, 30-53. https://doi.org/10.1257/000282806776157759

Dumitrescu, E. I., \& Hurlin, C. (2012). Testing for Granger Non-Causality in Heterogeneous Panels. Economic Modelling, 29, 1450-1460.

https://doi.org/10.1016/j.econmod.2012.02.014

Eberhardt, M., \& Teal, F. (2011). Econometrics for Grumblers: A New Look at the Literature on Cross-Country Growth Empirics. Journal of Economic Surveys, 25, 109-155. https://doi.org/10.1111/j.1467-6419.2010.00624.x

Graeber, D. (2011). Debt: The First Five Thousand Years. New York: Melville House.

Isanzu, J. S. (2017). The Impact of Credit Risk on the Financial Performance of Chinese Banks. Journal of International Business Research and Marketing, 2, 14-17. https://doi.org/10.18775/jibrm.1849-8558.2015.23.3002

Kajola, S. O., Olayiwola, P. O., \& Ekpudu, J. E. (2018). Working Capital Management Practices and Profitability in Nigeria. Izvestiya, Varna University of Economics, No. 3-4, 200-218.

Kiselakova, D., \& Kiselak, A. (2014). Analysis of Macroeconomic Factors for the Establishment of Industrial Parks and Their Effects on Regional Development: Empirical Study from Slovakia. Asian Economic and Financial Review, 4, 1220.

Kumbhar, V. M. (2009). Alternative Banking: A Modern Practice in India. Professional Banker, 9, 54-58.

Madhavi, E., \& Prasad, M. S. V. (2015). Assessing Corporate Performance with Measures of Value Added as Key Drivers of Shareholder Wealth: An Empirical Study. IUP Journal of Business Strategy, 12, 19.

Mensah, I. A., Sun, M., Gao, C., Omari-Sasu, A. Y., Zhu, D., Ampimah, B. C., \& Quarcoo, A. (2019). Analysis on the Nexus of Economic Growth, Fossil Fuel Energy Consumption, $\mathrm{CO}_{2}$ Emissions and Oil Price in Africa Based on a PMG Panel ARDL Approach. Journal of Cleaner Production, 228, 161-174. https://doi.org/10.1016/j.jclepro.2019.04.281

Muriithi, J. G. (2016). Effect of Financial Risk on Financial Performance of Commercial Banks in Kenya. Doctoral Dissertation, Cohred.

Mutura, E., \& Omagwa, J. (2018). Credit Management Practices and Financial Performance of Microfinance Institutions in Nairobi Central Business District, Kenya. International Journal of Scientific and Education Research, 2, No. 4.

Pedroni, P. (1999). Critical Values for Cointegration Tests in Heterogeneous Panels with Multiple Regressors. Oxford Bulletin of Economics and Statistics, 61, 653-670.

Pesaran, M. H. (2004). General Diagnostic Tests for Cross Section Dependence in Panels.

Pesaran, M. H. (2007). A Simple Panel Unit Root Test in the Presence of Cross-Section Dependence. Journal of Applied Econometrics, 22, 265-312. https://doi.org/10.1002/jae.951

Pesaran, M. H., Ullah, A., \& Yamagata, T. (2008). A Bias-Adjusted LM Test of Error Cross-Section Independence. The Econometrics Journal, 11, 105-127. https://doi.org/10.1111/j.1368-423X.2007.00227.x

Pesaran, M. H., \& Yamagat, T. (2008). Testing the Slope Homogeneity in Large Panels. Journal of Econometrics, 142, 50-93. https://doi.org/10.1016/j.jeconom.2007.05.010

Rasika, D. G. L., \& Sampath, H. R. (2015). Impact of Credit Risk on Financial Perfor- 


\section{Z. M. Tan et al.}

\section{mance of Sri Lankan Commercial Banks.}

Westerlund, J. (2008). Panel Cointegration Tests of the Fisher Effect. Journal of Applied Econometrics, 23, 193-233. https://doi.org/10.1002/jae.967 